\title{
Agrarian insurance in Russia: condition, difficulties, and ways of their overcoming
}

\author{
Alexey Nosov*, Olga Tagirova, and Marina Fedotova \\ Department of Finance, Penza State Agrarian University, 440014 Penza, Russia
}

\begin{abstract}
The article discusses the history of the development of state support for the agrarian producers sector in Russia and, in particular, the federal system of subsidizing agrarian insurance. It is shown that the main problems that violate the further progressive development of the agrarian insurance market are the destabilization of subsidies, the prevalence of compulsory insurance elements, the imperfection of legal support of insurance business and taxation of insurance activities, the decrease in the solvency of the population, the lack of clarity of state policy, and insufficient insurance culture of agrarian producers. The main directions of the development of agrarian insurance are proposed, one of which is the development of pilot projects for agrarian income insurance. It was analyzed on the experience of agrarian producers insurance in the USA and Canada, which led to the identification of the most critical factors that must be taken into account when developing the structure of income insurance. It is concluded that the essential factors in the development of agrarian insurance are the availability of the necessary volume of data on prices and the level of productivity in the region and sufficient support from the state.
\end{abstract}

\section{Introduction}

Nowadays, severe sanctions conditions for the country have led to an increase in the importance of the activities of Russian agrarian insurers, since it is agriculture that turns out to be the growth driver of the Russian economy and Russia's competitive advantage. At the same time, a significant part of the territory of the Russian Federation falls on the risky farming zone, where fires, droughts and floods, spring and early autumn frosts often occur. Losses of production and farm incomes are often so severe that they threaten their viability and harm the agrarian industrial complex of Russia as a whole. This situation demonstrates the need to develop an effective agrarian risk management system, and in particular agrarian insurance.

\section{Methods and materials}

This study is based on the following methods of economic research: empirical methods such as observation and fact-finding, general scientific methods such as scientific abstraction methods, analysis, and synthesis, systems approach methods, induction and deduction, historical, logical, and graphical methods.

\section{Results and discussion}

Between 2012 and 2016 In Russia, a federal system of subsidizing agrarian insurance was formed and, in general, debugged. Subsidies for state support of agrarian insurance were allocated to the regions in a targeted manner within limits provided for in the federal budget (up to 5 billion rubles for insurance of crop production risks and up to 500 million rubles for animal insurance in agriculture).

In 2017, the Government of the Russian Federation adopted Decree No. 1556 "On the provision and distribution of subsidies from the federal budget to the budgets of the constituent entities of the Russian Federation to facilitate the achievement of target indicators of regional programs for the development of the agrarian industrial complex." As a result, many areas of state support were included in the "single subsidy" after the adoption of this Decree. At the same time, the specifics of agrarian insurance was not taken into account. These circumstances resulted in a 3.5-fold reduction in the volume of support for agrarian insurance. The destabilization of subsidies has become the main threat to the agrarian insurance system in Russia [1, p. 58].

As part of the inclusion of agrarian insurance in the "single subsidy," the regions received the right to more dynamically manage the funds of federal appropriations, independently redistributing them from one direction to another. However, in the absence of the task of organizing insurance coverage for farmers, the regions preferred to direct financing mainly for production purposes. As a result, the amount of the listed subsidies for crop insurance fell almost 4 times compared to 2016 - to 529 million rubles, the volume of subsidies for agrarian insurance in general - nearly 3 times, to 940 million rubles. In 2016, the total amount of subsidies amounted to 2.6 billion rubles, since due to changes in

Corresponding author: a nosov83@mail.ru 
the state support procedure, subsidies for autumn sowing insurance were reduced [2, p. 41].

In 2018, one of the main tasks for the agrarian insurance system was to prevent the threat of its destruction as a result of the negative phenomena of the transition of the regions to a new order of state support.

Law No. 260-FL "On state support in the field of agrarian insurance ..." introduced amendments that allow insurance of crops and animals at a reduced cost due to the expanded range of available deductibles and insurance amounts, which enables agribusiness bodies to subsidize a more significant number of agrarian industrial agreements insurance within the limits of available financing limits.

Nevertheless, the agrarian insurance market in Russia is going through a difficult period. Despite the law that came into force, many unresolved issues remain in the industry that does not allow the use of insurance as a system of financial protection of the interests of the state, enterprises, and citizens. The main factor holding back the development of agrarian insurance remains the instability of subsidies.

The following issues need to be addressed:

- prevalence of elements of compulsory insurance, while voluntary types should be decisive for the development of insurance;

- the imperfection of legal support of insurance business and taxation of insurance activities;

- regional clustering of the agrarian insurance market, developing mainly where agrarian production is the most investment-attractive;

- a decrease in the solvency of the population, which makes it impossible to increase the insurance portfolio of insurers, and a small assortment of insurance services;

- insufficiently clear government policy in the insurance market;
- low legal regulation (in particular, the lack of a regulatory framework that allows you to determine the procedure and essential criteria for assessing damage);

- insufficient insurance culture of agrarian producers and a low level of public confidence to insurance companies [3, p. 94].

In general, in 2017, a decline in most indicators was observed in the agrarian insurance market with state support. In 2017, in the field of crop production, insurance was provided by 17 insurance organizations in 32 constituent entities of the Russian Federation (Table 1).

The number of agrarian producers to whom a subsidy was paid to pay part of the insurance premium under agrarian crop insurance and permanent planting insurance contracts in 2017 decreased by 2.8 times compared to 2016. The size of this indicator is minimal over the past five years and amounts to 321 agrarian producers. In 2014, the maximum number of farms that concluded that insurance contracts with state support was noted. The number of peasant (farmer) farms and individual entrepreneurs who received a subsidy to pay part of the insurance premium under contracts for insurance of crop crops and planting of perennial plants, in 2017 compared to the previous year decreased by 3.4 times, and agrarian organizations decreased by 2.8 times.

In 2017, the number of agrarian producers to whom subsidies were paid to pay part of the insurance premium under agrarian animal insurance contracts amounted to 274 , which is $3.2 \%$ lower than in 2016 and is the minimum for five years. Moreover, this figure is 1.9 times less than in 2014 (526 agrarian producers). The share of the insured livestock reached the highest level in 2015, after which it began to decline and in 2017 amounted to $13.7 \%$ (Table 2).

Table 1. Development dynamics of crop insurance of crops and perennial plantings with state support.

\begin{tabular}{|c|c|c|c|c|c|c|}
\hline Indicator & 2013 & 2014 & 2015 & 2016 & 2017 & $\begin{array}{c}\text { Indicators of } 2017 \\
\text { to the indicators of } \\
2016, \%\end{array}$ \\
\hline $\begin{array}{l}\text { The number of organizations that have concluded insurance } \\
\text { contracts to be subsidized - total }\end{array}$ & 4663 & 5827 & 2751 & 913 & 321 & 35.2 \\
\hline including agrarian organizations & 2701 & 3442 & 1854 & 774 & 280 & 36.2 \\
\hline including peasant (farm) enterprises and individual entrepreneurs & 1962 & 2385 & 897 & 139 & 41 & 29.5 \\
\hline Sown (planting) area - total, million hectares & 74.7 & 75.0 & 75.9 & 76.7 & 77.5 & 101.0 \\
\hline $\begin{array}{l}\text { including: } \\
\text { sown (landing) area under insurance contracts, million ha }\end{array}$ & 11.7 & 12.8 & 8.3 & 3.8 & 1.8 & 47.4 \\
\hline The proportion of the insured sowing (planting) area, $\%$ & 15.7 & 17.1 & 10.9 & 5.0 & 2.3 & $\mathrm{X}$ \\
\hline $\begin{array}{l}\text { The number of subjects of the Russian Federation participating in } \\
\text { insurance }\end{array}$ & 60 & 62 & 56 & 40 & 32 & 80.0 \\
\hline $\begin{array}{l}\text { The number of insurance organizations providing crop insurance } \\
\text { for crops and plantings of perennial plantings with state support }\end{array}$ & 42 & 44 & 43 & 21 & 17 & 81.0 \\
\hline Sum insured, million rubles & 183128 & 212584 & 155707 & 114782 & 37664 & 32.8 \\
\hline The amount of insurance premium paid, million rub. & 10653.0 & 12265.2 & 8709.7 & 5657.7 & 1523.2 & 26.9 \\
\hline Subsidies from the federal budget, million rubles & 4397.1 & 4931.0 & 3827.9 & 2342.5 & 693.0 & 29.6 \\
\hline $\begin{array}{l}\text { Subsidies from the budgets of the constituent entities of the } \\
\text { Russian Federation, million rubles }\end{array}$ & 690.0 & 1141.1 & 401.1 & 172.6 & 63.7 & 36.9 \\
\hline The share of subsidies in the paid insurance premium, $\%$ & 49.3 & 49.2 & 49.1 & 44.5 & 49.7 & $\mathrm{X}$ \\
\hline The amount of insurance compensation, million rubles & 1454.5 & 1561.1 & 1072.9 & 629.6 & 168.2 & 26.7 \\
\hline $\begin{array}{l}\text { The ratio of the amount of insurance compensation to the paid } \\
\text { insurance premium, } \%\end{array}$ & 13.7 & 12.7 & 12.3 & 11.1 & 11.0 & $\mathrm{X}$ \\
\hline
\end{tabular}


Table 2. Dynamics of development of farm animal insurance with state support

\begin{tabular}{|c|c|c|c|c|c|c|}
\hline Indicator & 2013 & 2014 & 2015 & 2016 & 2017 & $\begin{array}{c}\text { Indicators of } 2017 \\
\text { to the indicators of } \\
2016, \%\end{array}$ \\
\hline $\begin{array}{l}\text { The number of organizations that have concluded insurance } \\
\text { contracts to be subsidized }\end{array}$ & 371 & 526 & 345 & 283 & 274 & 96.8 \\
\hline including agrarian organizations & 332 & 429 & 311 & 260 & 269 & 103.5 \\
\hline $\begin{array}{l}\text { including peasant (farm) enterprises and individual } \\
\text { entrepreneurs }\end{array}$ & 39 & 97 & 34 & 23 & 5 & 21.7 \\
\hline Livestock - total, thousand conventional heads & 24596 & 25905 & 26637 & 27688 & 28280 & 102.1 \\
\hline $\begin{array}{l}\text { including livestock of farm animals under insurance contracts, } \\
\text { thousand conventional units }\end{array}$ & 1728 & 4302 & 4776 & 4045 & 3879 & 95.5 \\
\hline The proportion of the insured livestock, $\%$ & 7.0 & 16.6 & 17.9 & 14.6 & 13.7 & 93.8 \\
\hline $\begin{array}{l}\text { The number of subjects of the Russian Federation participating } \\
\text { in insurance }\end{array}$ & 38 & 57 & 51 & 47 & 45 & 95.7 \\
\hline $\begin{array}{l}\text { The number of insurance organizations providing insurance for } \\
\text { farm animals with state support }\end{array}$ & 28 & 31 & 22 & 13 & 8 & 61.5 \\
\hline Sum insured, million rubles & 37567 & 70133 & 82485 & 66007 & 95101 & 144.1 \\
\hline Amount of insurance premium paid, million rubles & 417 & 813 & 839 & 724 & 876 & 120.9 \\
\hline Subsidies from the federal budget, million rubles & 166 & 291 & 362 & 237 & 354 & 149.7 \\
\hline $\begin{array}{l}\text { Subsidies from the budgets of the constituent entities of the } \\
\text { Russian Federation, million rubles }\end{array}$ & 40.5 & 101.9 & 42.7 & 29.3 & 62.6 & 213.7 \\
\hline The share of subsidies in the paid insurance premium, $\%$ & 49.5 & 48.3 & 48.3 & 36.7 & 47.6 & 129.6 \\
\hline The amount of insurance compensation, million rubles & - & 8.9 & - & 139.1 & 53.2 & 38.2 \\
\hline $\begin{array}{l}\text { The ratio of the amount of insurance compensation to the paid } \\
\text { insurance premium, } \%\end{array}$ & - & 1.1 & - & 19.2 & 6.1 & 31.6 \\
\hline
\end{tabular}

In 2018, 367 contracts for a total insurance amount of 23.7 billion rubles were concluded on crop and perennial plant insurance under subsidized conditions. The insurance premium is accrued in the amount of 989 million rubles.

A total of 1.2 million hectares of sown area was insured, which amounted to $1.5 \%$ of the total sown (planting) area of the country.

The main objects of insurance were grain crops, which account for $82 \%$ of the total area of insured sowing, as well as oilseeds, fodder, and industrial crops. About 591 thousand ha, or $51 \%$ of the insured area, falls on winter sowing (including, in the segment of grain crops, winter species account for $62 \%$ of all insured regions). There was a decrease in the volume of risks transferred to insurance: the average insurance amount per crop insurance risk insurance contract decreased from 82.3 million rubles to 55.5 million rubles, the average insurance premium decreased from 3.1 million rubles to 2.3 million rubles.

In 2018, agrarian insurers on livestock risk insurance concluded 328 insurance contracts on a subsidized basis for a total liability of 101.7 billion rubles. The accrued insurance premium reached 1.0 billion rubles (in 2017 876.3 million rubles). In total, 4.8 million conditional goals were insured as part of state support, which amounted to about $16.7 \%$ of the total population. The most extensive insurance coverage with state support was achieved in pig breeding -5.9 million heads of pigs, or about $25 \%$ of the livestock, were insured, and also in poultry farming - the insured animal (99.9 million heads) is $18 \%$ of the number of poultry.

We can conclude that the situation is unfavorable in the agrarian insurance system with state support. About $15 \%$ of the cultivated area and about $18 \%$ of the livestock receive insurance coverage, although the state subsidizes agrarian producers $50 \%$ of the cost of insurance. The modern system of state support for agrarian insurance cannot stimulate the mass participation of farmers in insurance and ensure the formation of their reliable insurance protection [4, p. 54]. The reasons are the low interest of insurance companies and agrarian producers, the imperfection of the regulatory framework, and the underdeveloped infrastructure of the insurance market [5, p. 91].

The effective development of agrarian insurance in Russia certain transformations should be carried out. First of all, it is necessary to understand that state support for agrarian insurance should be aimed at meeting the interests of farmers, and not insurance companies. The ultimate goal of such support should be the availability and very agrarian insurance with high compensation for losses through the effective use of budget resources [3, p. 99].

The necessary development of agrarian insurance is possible with the implementation of its following principles: self-sufficiency of insurance resources; their mass, accessibility and accumulation; reasonable adjustment of insurance rates in the event of a change in the frequency of insured events; differentiation of insurance conditions by region; imputation of catastrophic risk insurance; a sufficient variety of insurance schemes; reinsurance; the ability to choose insurance terms; adequate state support; use of other risk management tools [6, p. 47].

Following these principles, we have formulated the main directions for improving the agrarian insurance system with state support in the Russian Federation (Fig. 1). 
1) According to the current legislation, an insured event is the loss of crops in $20 \%$ or the loss of viability of perennial plantings on more than $30 \%$ of the area. Any decrease in yield compared with the average value is proposed to be considered an insurance case considered by the insurance company. Moreover, for a more accurate assessment, it would be advisable to use more typical average values instead of the arithmetic average when calculating the average yield. A more objective indicator is the modal or median value. A median is a number that is in the middle of the ranked row; that is, half of the sample elements are more significant than it, and the other half is less than it is. This average underestimates higher yields and overestimates low ones, thereby equalizing crop yields for the period under consideration.

\section{The main directions of development of agrarian insurance with state support}

Recognition by an insured event of any decline in crop yields in comparison with the average median value over five years

Withdrawal of agricultural insurance from the "single" subsidy

Development of a catastrophic risk insurance program with a minimum level of insurance coverage

Clarification of the procedure for calculating insurance value taking into account inflation and exclusion from the calculation of years with abnormally low and abnormally high crop yields

Improving the institutional environment of agrarian insurance

Development of pilot projects for agrarian income insurance

Fig. 1. The main provisions of the development strategy of the agrarian insurance system.

2) Since 2017, state support for agrarian insurance has been carried out as part of the "single subsidy." The new rules have become a de facto departure from the entire existing system since a gap has formed in the regulatory framework, the general rules for the interaction of agribusiness, agrarians, and insurers have become unclear. The consequences of introducing a "single subsidy" were quite severe. The regions, first of all, focus on financing current production tasks. Besides, they lack the resources to provide preferential loans for crops, which is also included in the "single subsidy." Subsidizing agrarian insurance should be an independent tool to support farmers.

3) In support of insurance, the main emphasis should be placed on the full protection of agrarian producers from catastrophic losses due to natural disasters, cumulatively affecting a large number of farms and extensive territories. Therefore, the catastrophic risk insurance program with a minimum level of insurance coverage to ensure "self-sufficiency" and "mass" insurance should occupy a particular place in the composition of agrarian insurance programs. The cost of this insurance policy should be relatively affordable for payment by agrarian producers. This approach implementation, a catastrophic threshold should be established for each region concerning a limited list of main crops at a level of at least $40 \%$ of the average annual yield. The tariff for this program could be determined in the amount of 2-3\%, and also increase the share of state subsidies to $60 \%$. A low tax will make insurance less burdensome and will expand agrarian insurance coverage.

4) According to the methods of mathematical statistics, the minimum and maximum values of the variational series show the scatter of the values of the attribute in a given sample. If one of them or both significantly differs from the others, they must be excluded from the sample, since their consideration can distort the calculated value of the average value of the series. Therefore, when calculating the average yield, abnormal years in terms of political, economic, and climatic parameters should be excluded.

5) Improving the institutional environment of agrarian insurance with state support is an essential and indispensable condition for the effective functioning of the entire system. In this regard,

- several changes should be introduced into the legislation, which concerns the clarification of the specifics of agrarian insurance with state support, the definition of its purpose and fundamental principles, the introduction of provisions on cooperative and mutual insurance, to link imputation of insurance to catastrophic risk insurance;

- it is necessary to clarify the calculations of the insured value and insurance damage by excluding the abnormal years when calculating the average annual yield and taking into account the indexation of compensation for inflation;

- accelerate the process of dispute resolution and reduce costs, institutions for the pre-trial settlement of disputes should be developed and supported;

- accumulate complete and reliable weather information in the regions; it is advisable to expand the network of weather stations with modern equipment, to improve the quality of forecasts of natural phenomena.

6) The development of pilot projects for the insurance of income of agrarian producers in connection with the successful experience of applying for income insurance in other countries, which is especially necessary in case of the instability of the economic situation in the country and the world, becomes relevant.

Today in Russia, as in other developed countries of the world, the most general insurance against weather risks. Despite the difficulties associated with insurance against various weather events, modern comprehensive insurance programs cover almost the entire range of possible threats. Agrarian insurance is also developing in the livestock industry with its specific risks [7, p. 93]. 
However, price fluctuations on world agrarian markets in the context of globalization have such an effect on national and regional markets that it becomes more difficult to ignore such risks. Over the past years, most developed economies in the world have addressed the issue of price risk management. At the same time, only two countries achieved practical success in introducing income insurance programs for farmers: the USA and Canada [8, p. 1999]. Based on the experience of these countries, it is possible to formulate the most important factors that must be taken into account when developing the structure of such insurance:

- the availability of the necessary volume of data on prices and the level of productivity in the region;

- sufficient support from the state, both in terms of regulating these activities and financial support [9, p. 125].

In essence, income insurance is insurance of the gross proceeds of the producer from the sale of the expected crop at the estimated price (i.e., the amount agreed upon at the stage of sowing the plant, which the producer uses as the basis for calculating the volume of investments in crop production). If the price decreases at the time of harvest below the level guaranteed by the insurance product, insurance indemnity is paid. It does not matter for what reason the decline occurred: due to economic and (or) weather factors. The franchise level (the difference between guaranteed and actual income) is considered advisable to set at $10-15 \%$. Thus, from risk analysis, the insurance product assumes insurance protection against two types of risks (weather and economic, that is, yield and income), which increases the likelihood of paying insurance compensation [10, p. 136].

Considering the relevance of income insurance, it is worth noting that agrarian producers can reduce the level of price risk by their methods. First of all, he can conclude a forward contract for the sale of future products at a fixed price. In this case, as a rule, a guarantee of the supply of a specific volume is required. Therefore, with a decrease in yield (for example, due to weather conditions), the farmer will be forced to purchase the missing volume in the market. If the crop is insured, there is no problem.

Consequently, crop insurance is the primary condition for managing price risk. However, factors are limiting the effectiveness of forwarding contracts as a tool for managing price risks.

Firstly, the seller and the buyer may not agree on a minimum (fixed) price. Moreover, secondly, if there is a massive decrease in productivity in the region, prices for this type of product may increase so much that crop insurance does not reimburse the costs of the agrarian on the forward contract. Also, the manufacturer can hedge price risks in the financial market, which is possible by purchasing options or selling futures.

For an effective income insurance system, it is necessary to have reliable data on three main components: price, yield, and the relationship of cost with the return. Moreover, each element should be measurable and quantifiable, and the analyzed period of at least 15 years. Wheat is often used as a world grain price, as it is the main food crop for most countries.
Let us analyze how the prices for this type of product have changed in the global and national markets over the past 20 years (Fig. 2).

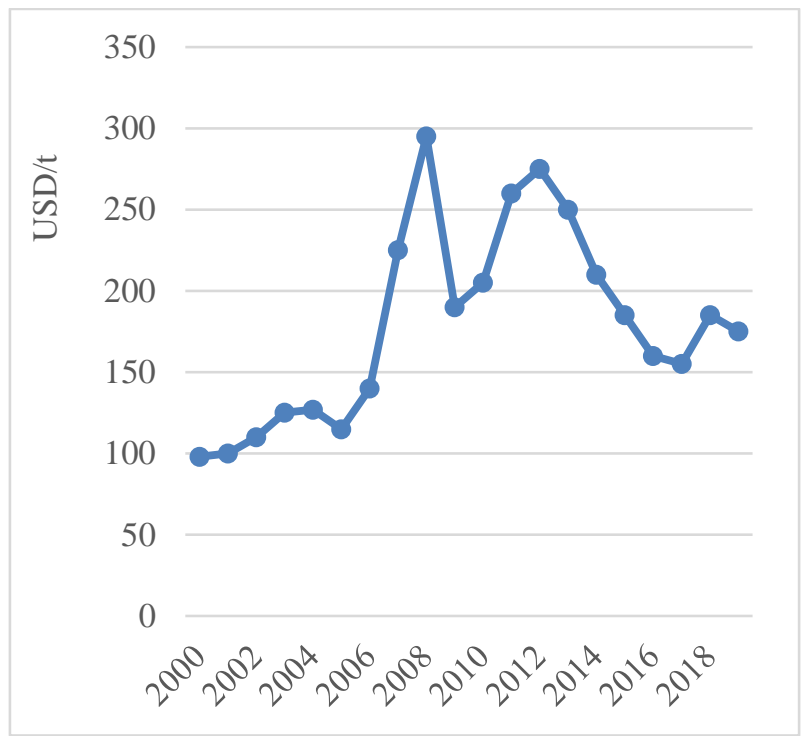

Fig. 2. Dynamics of world wheat prices, USD / $t$

According to the Fig. 2, we can conclude that since 2005 , the market is unstable. A sharp rise in wheat prices gave way to a fall in 2009. After a short stabilization of the situation, price reduction has been going on for four years, and soon, the negative trend is unlikely to be reversed. Experts attribute this to a high wheat yield and record world reserves.

Moreover, the situation in the national market is different. Since Russia is a significant exporter of grain, domestic prices directly depend on world market prices and the ruble exchange rate. Therefore, after each weakening of the ruble, wheat in the country inevitably rises in price (Fig. 3).

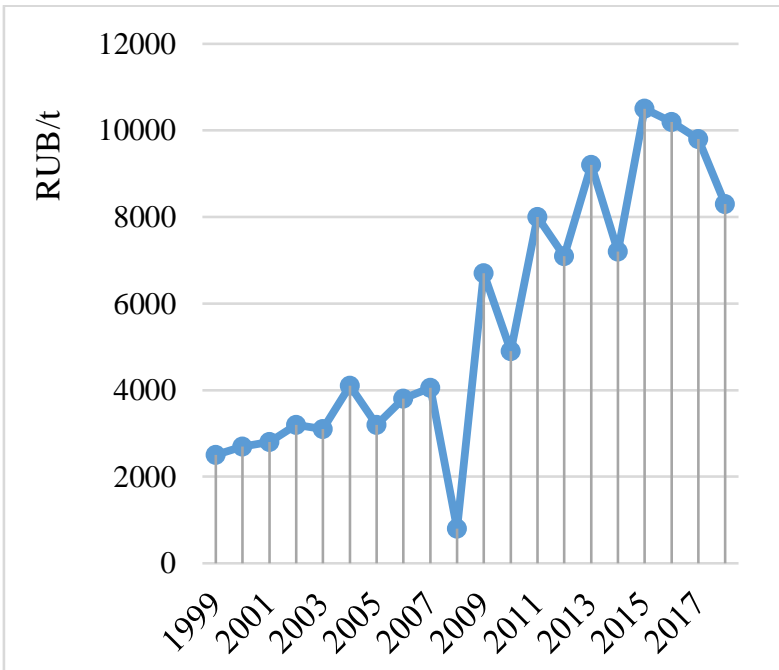

Fig. 3. Dynamics of Russian wheat prices, RUB / $t$

Despite the multidirectional price trends in recent years, the correlation coefficient showing the interdependence of Russian and world wheat prices is 0.66 . This indicates the presence of a reasonably long relationship between the direction indicators. This fact is 
important because income can be insured only in countries with a high correlation of national and global prices for the corresponding goods [11, p. 100].

Changes in wheat yields in Russia are presented in Fig. 4.

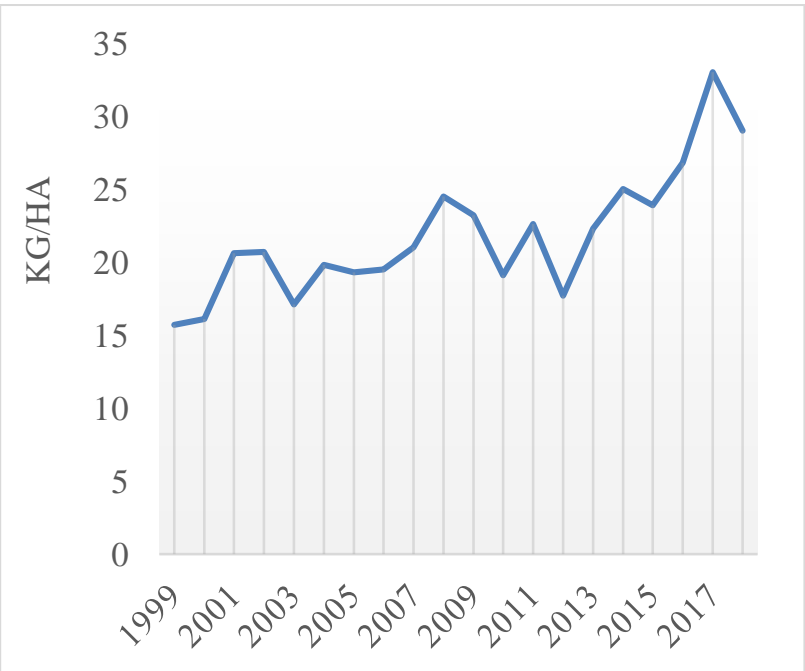

Fig. 4. Dynamics of wheat productivity in Russia, $\mathrm{kg} / \mathrm{ha}$

Wheat yield tends to increase. In 2018, it amounted to $29.1 \mathrm{~kg} / \mathrm{ha}$.

The relationship between yield and price is an essential aspect that determines the likelihood of a loss in the future. With a decrease in both indicators, the insurer pays compensation in the highest amount. Ideally, the correlation should be inverse. Nevertheless, this can only take place if the level of productivity at the regional level does not affect the formation of global prices alternatively, if global prices depend on external factors, such as a drop in demand due to the worldwide crisis. In this case, the price level may not rely on the volume of production.

Thus, the highest priority for a country wishing to create an income insurance program is to analyze the worst-case scenario for the most systemic risk, in this case, namely price risk. However, to determine the correlation between the level of yield and price, you need a database for a sufficiently long period and the ability to correlate levels of yield and rate.

Determine the needs of Russian agrarian producers in income insurance; it is necessary to establish the relationship of productivity not only with prices on the national market but also with world prices.

Using the MS Excel add in "Data Analysis," you can find the correlation coefficient between these two indicators. The value of the factor 0.54 indicates the current direct linear dependence, i.e., an increase in yield in Russia is taking place against the backdrop of rising world prices. Consequently, it is beneficial for Russian agrarians involved in wheat export to conclude an income insurance contract, since there is a possibility of a decrease in both indicators simultaneously.

After conducting a similar analysis for Russian wheat prices, we can conclude that there is an even more significant relationship between rate and yield. The correlation coefficient is 0.77 . This leads to the conclusion that income insurance is highly attractive for Russian agrarian producers involved in the cultivation and sale of wheat in the domestic market.

Taking into account the data presented in this study and their analysis, we can conclude that the price risk management means, such as income insurance, is more convenient and more reliable than the farmers' means.

\section{Conclusion}

The improvement of the existing system of agrarian insurance should not be limited solely to the above recommendations. The proposed tools can become the basis for building an effective agrarian insurance system with state support in the Russian Federation. A stable and effective agrarian insurance system is not only a tool to support farmers, but also a promising direction of insurance for insurers. The development and successful implementation of agrarian insurance programs should become a source of growth in the financial results of Russian insurance companies.

\section{References}

1. T.A. Verezubova, K.A. Zhichkin, A.M. Mukhitbekova, Crop risks insurance in Russia, Belarus and Kazakhstan, Finances, 10, 5560 (2018)

2. T.A. Baimisheva, Index insurance of agrarian risks, Economics of farming and processing enterprises, 3, 41-42 (2017)

3. B.A. Voronin, E.M. Kot, E.V. Matveev, A.G. Mokronosov, On the development of agrarian insurance in modern Russia, Agrar. Bull. of the Urals, 06(148), 94-100 (2016)

4. I.V. Shevchenko, V.V. Chistyakov, Agrarian risk insurance with state support: problems and solutions, Finance and Credit, 43(619), 54-60 (2018)

5. A.A. Nazarova, Improve state support for agrarian insurance, AIC: economics, Management, 8, 87-93 (2015)

6. Yu.M. Makhdieva, M.M. Saadueva, To the question of the need to reform the Russian agrarian insurance system, Managem. of econ. syst.: electr. sci. J., 9(57), 47 (2013)

7. G.R. Valieva, L.F. Khazeyev, The risk management system as the basis of the financial stability of the enterprise (on the example of the enterprise of the agrarian industrial complex of the Republic of Tajikistan), Bull. of Kazan State Agrar. Univer., 12(2(44)), 93-97 (2017)

8. E.T. Prokopchuk, World experience of state regulation of the agrarian insurance market (literature study), Finance and Credit, 23(33(753)), 1997-2014 (2017)

9. O.A. Tagirova, O.V. Novichkova, A.V. Nosov et al., Financial risks of agrarian organizations: classification, assessment, Management (RIO PGAU, Penza, 2017) 
10. A.V. Nosov, O.A. Tagirova, T.F. Boryaeva, O.V. Novichkova, Agrarian insurance as an instrument of financial support for agriculture under the conditions of sanctions, Niva Volga, 2(35), 131137 (May 2015)
11. K.A. Naminova, The current state of risk insurance of agrarian organizations with state support in Russia, Approbation, 7(46), 100-105 (2016) 